\title{
Comparison of clast and matrix dispersal in till: Canterbury area, New Brunswick
}

\author{
Solweig A. Balzer* and Bruce E. Broster** \\ Quaternary and Environmental Studies Group, Department of Geology, University of New Brunswick, \\ Fredericton, New Brunswick E3B 5A3, Canada
}

Date Received August 18, 1993

Date Accepted December 6, 1993

\begin{abstract}
Matrix granulometric and geochemical components were compared with clast lithology for 247 samples of basal till, collected on a $2 \mathrm{~km}^{2}$ grid from the Canterbury area in south-central New Brunswick. Plots of component concentrations outlined dispersal patterns elongated southeastward and southward, paralleling the last directions of glacial flow. A comparison of these data indicated that dispersal pattern size was influenced by sample spacing and elevation of source during glacial incorporation. At a given sample grid, clast lithologies formed relatively larger and more recognizable dispersal patterns and thus better exploration targets. Geochemical dispersal patterns were localized and rarely exceeded $6 \mathrm{~km}$ in length. Element anomalies could be traced to known mineral occurrences, but for most elements dispersal patterns were less than $4 \mathrm{~km}$ long and defined by one to three sample sites. Clast dispersal patterns could be traced up to $12 \mathrm{~km}$ down-ice of source units.

Till components were incorporated locally and reflected short transport distances. Till matrix was homogeneously mixed and deposited by a single glacier as it flowed south and southeastward across the area.
\end{abstract}

La granulométrie de la matrice et la composition géochimique furent comparés avec la lithologie des clastes pour 247 échantillons de till de base, prélevés sur une grille de $2 \mathrm{~km}^{2}$ dans la région de Canterbury dans le centre-sud du NouveauBrunswick. La mise en plan des concentrations des composants ont indiqué des patrons de dispersion allongés vers le sud-est et le sud, parallèles aux dernières directions de l'écoulement glaciaire. Une comparaison de ces données a indiqué que la dimension du patron de dispersion était influencée par la maille d'échantillonnage et l'altitude de la source lors de l'incorporation dans la masse de glace. $\dot{A}$ une certaine maille, les lithologies des clastes formèrent des patrons de dispersion relativement plus grands et plus distincts et ainsi de meilleures cibles pour l'exploration. Les patrons de dispersion géochimiques furent localisés et n'excédèrent que rarement $6 \mathrm{~km}$ de longueur. Les anomalies en certains éléments purent être suivies jusqu'à des indices minéralisés connus, mais pour la plupart des éléments, les patrons de dispersion avaient moins de $4 \mathrm{~km}$ de longueur et n'étaient indiqués que par un à trois sites d'échantillonnage. Les patrons de dispersion des clastes purent être suivis jusqu'à $12 \mathrm{~km}$ en aval des unités qui en sont les sources.

Les composants du till furent incorporés localement et reflétaient de courtes distances de transport. La matrice du till fut mélangée de façon homogène et déposée par un seul glacier pendant qu'il s'écoulait vers le sud et le sud-est dans cette région.

[Traduit par la rédaction]

\section{INTRODUCTION}

Dispersal analyses, using clast lithology and geochemistry of glacial sediments, have long been used as an exploration tool in Canada (Dreimanis, 1958; Shilts, 1976, 1984; Hicock, 1986; McConnell and Batterson, 1987; Coker and DiLabio, 1989; DiLabio, 1990). A dispersal pattern or "train" is recognized by contouring anomalous values of till components, thus identifying an enriched zone that can be traced to an up-ice source (e.g., Dreimanis, 1958; Shilts, 1976; Coker and DiLabio, 1989; DiLabio, 1990). According to Shilts (1976), well-defined dispersal trains are finger- or ribbon-shaped. Variations in the pattern may be attributed to changes in ice-flow direction, physiographic influences or multiple ice-flow events. In areas where rock units are few, distinctive lithologies can be easily traced and classified. However, dispersal patterns originating from a range of lithologies or multiple sources, can form complex trains.

*Present Address: Department of Geology, University of Alberta, Edmonton, Alberta T6G 2E3, Canada

**Corresponding Author
Recent studies in New Brunswick have demonstrated success in delineating source units by examination of dispersal patterns from analyses of till matrix (Hornibrook et al., 1991, 1993). Reports suggest that tills in the study area are locally derived (Broster and Seaman, 1991; Balzer, 1992) with short ( $<4 \mathrm{~km}$ ) dispersal patterns for heavy minerals and geochemical components. Research from other regions indicates that near the source, the local clast component of tills should always be larger (and thus form a larger dispersal train) than locally derived matrix components (Dreimanis and Vagners, 1971). Our objective was to undertake a comparative study to further examine any contrast in dispersal between the fine-grained geochemical matrix component and the coarse-grained clast component of till.

\section{LOCATION AND PHYSIOGRAPHY}

The study area is located in south-central New Brunswick, to the west of the Trans-Canada Highway between Fredericton and Woodstock (Fig. 1). The area comprises the whole of the Canterbury topographic map sheet (N.T.S. $21 \mathrm{G} / 14$, scale 1:50 


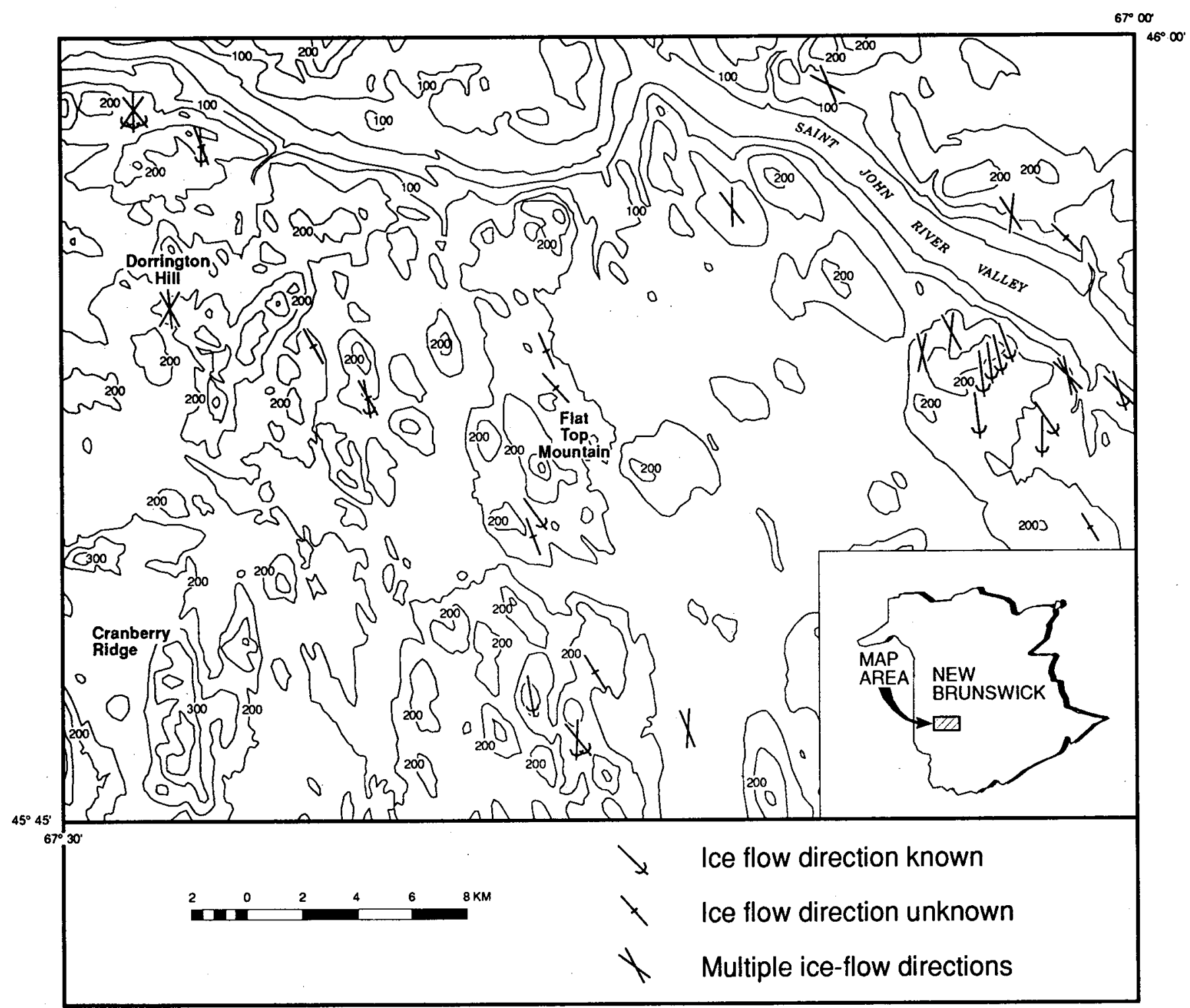

Fig. 1. Study area with $50 \mathrm{~m}$ contours and directions of glacial striae as indicated. Area location within the province of New Brunswick is shown in the map insert.

000 ). Due to high water tables and dense vegetation, much of the area is only accessible by foot or canoe.

The area is part of the St. Croix Highlands Physiographic Zone (Rampton et al., 1984), a subdivision of Bostock's (1970) Appalachian Region. The main physiographic feature in the area is the Saint John River, which flows southeastward across the northern portion of the study area (Fig. 1). The river occupies an entrenched valley, that rises to form a broad plateau punctuated by rock-cored hills and ridges, 200 to $300 \mathrm{~m}$ above local relief. In the central portion of the study area, the hills are separated by a broad, relatively flat area of swamps and peatland. Streamlined hills, elongated in a northwest-southeast direction, with elevations up to $400 \mathrm{~m}$, are abundant in the western and southwestern portions of the study area (Fig. 1).

\section{BEDROCK GEOLOGY}

Bedrock exposure in the study area is rare, occurring mainly along logging roads and on hill tops. Bedrock is commonly weathered to depths exceeding $1 \mathrm{~m}$, with the granite regolith occasionally exceeding $5 \mathrm{~m}$ in depth.

The Canterbury area is situated within three tectonostratigraphic zones: the Miramichi Terrane; the Fredericton Cover Sequence and the Carboniferous Cover Sequence, (Fyffe and Fricker, 1987; Ruitenberg et al., 1990). These zones are subdivided by lithology, structure and age (Lutes, 1979, 1987; Venugopal, 1979; Bevier, 1988; Whalen, 1993). In the southeast quarter of the study area (Fig. 2), the Fredericton Cover Sequence consists of Silurian low-grade metamorphic, marine sedimentary rocks. On the northern boundary of this zone. ironstained and fossiliferous Carboniferous sedimentary clastic rocks of the Carboniferous Cover Sequence (Fig. 2) occur as a small outlier along the Saint John River (Lutes, 1987).

In the northwestern corner of the area, units of the Miramichi Terrane (Fig. 2) occur as sequences of Cambrian to Ordovician sedimentary and volcanic rocks. The Miramichi units are deformed, metamorphosed, and unconformably overlain by Silurian to Devonian sedimentary and volcanic rocks 


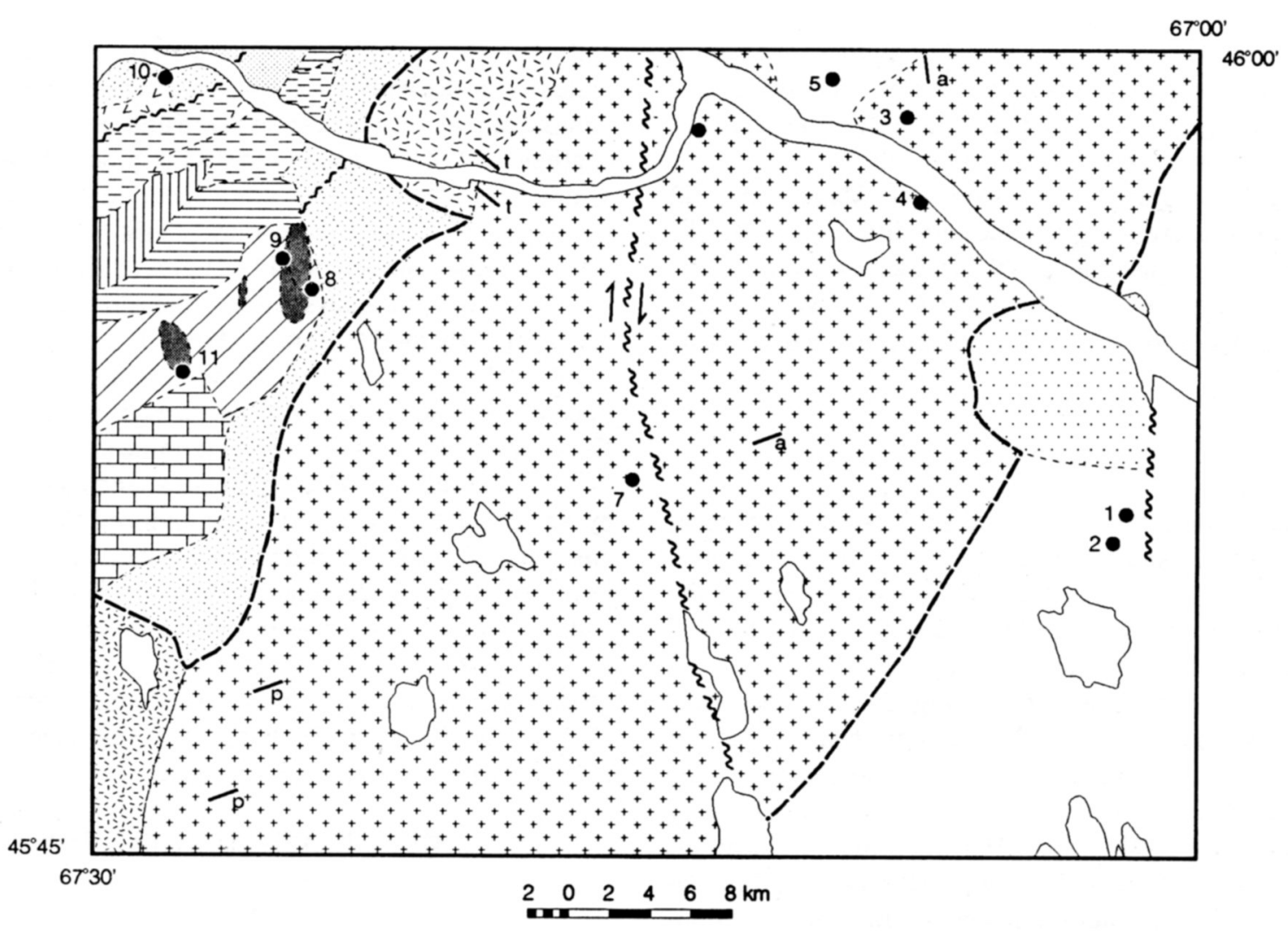

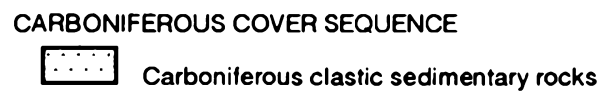

FREDERICTON COVER SEQUENCE

Silurian greywacke, slate and conglomerate

MIRAMICHI TERRANE

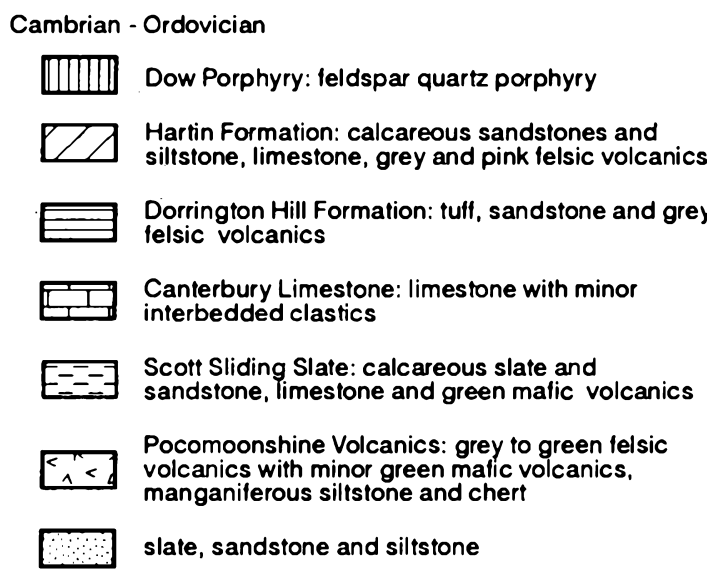

INTRUSIONS

Pokiok Batholith

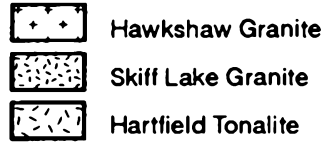

Dykes

diabase, gabro

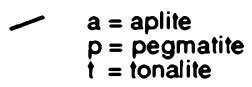

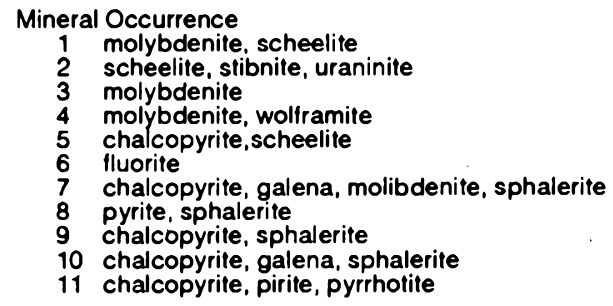

Fig. 2. Bedrock geology of the area after Anderson and Poole (1959); Lutes (1979, 1987); Venugopal (1979); Fyffe et al. (1981); Ruitenberg et al. (1990); Fyffe and Fricker (1987). The Pokiok Batholith units occupy the central area bounded by the heavier-dashed lines.

(Lutes, 1987). In this area the lithologies are repetitive (see Fig. 2) but have been intruded by diabase dykes, gabbro dykes and mafic volcanic rocks that are dark green in colour and serve as marker lithologies for our study.

The tectonostratigraphic zones are also intruded by the Late Silurian Pokiok Batholith and small dykes (Lutes, 1987; Bevier, 1988; Whalen, 1993). Over $60 \%$ of the study area is underlain by the Pokiok Batholith which extends in a broad band, north- east to southwest across the centre of the area (Fig. 2). The batholith separates the Fredericton Cover Sequence from the Miramichi Terrane and is subdivided into three units: the Hawkshaw Granite, the Skiff Lake Granite, and the Hartfield Tonalite (Lutes, 1987). The Hawkshaw Granite, largest of the units, ranges from granodioritic to granitic in composition, is grey to pink in colour and texturally is phaneritic to porphyritic. Xenoliths of metasedimentary and mafic rocks are com- 
mon (Lutes, 1987). Numerous small dykes (aplites, pegmatites and tonalites) intrude the Hawkshaw Granite. The dykes have distinctive lithologies and restricted occurrences, thus presenting useful point sources for our dispersal analyses.

The Skiff Lake Granite and the Hartfield Tonalite (Fig. 2) occur along the western margin of the batholith. The Skiff Lake Granite is similar in appearance to the Hawkshaw Granite. The Hartfield Tonalite is a grey, coarse-grained unit varying in composition from a hornblende-biotite tonalite to quartz-diorite (Lutes, 1987).

\section{Mineralization}

The Lake George Mine is located in the study area (locations 1 and 2: Fig. 2) and represents an area of anomalous antimony, arsenic and gold. In the mine area, minerals found in the Silurian turbidites include: scheelite, molybdenite, stibnite and uraninite. Lutes (1987) reports chalcopyrite and scheelite occurring west of Day Hill (location 5: Fig. 2). The only units currently known to contain mineralization in the northwestern part of the study area (Venugopal, 1979) are the Pocomoonshine Volcanics (recently renamed the Oak Mountain Formation by Van Staal and Fyffe, 1991) and the Hartin Formation (locations 10 and 11, respectively: Fig. 2). The Hawkshaw Granite is reported (Lutes, 1987) to contain some mineralization (e.g., fluorite, molybdenite, wolframite, chalcopyrite, galena and sphalerite).

\section{Glacial geology}

Most of the area is overlain by a blanket of till, which is in turn, overlain by Late Wisconsinan ice-contact and glaciofluvial sediments. The till is commonly found to be very similar in composition and appearance to underlying bedrock, due to the incorporation of highly weathered rock during glaciation (Broster and Seaman, 1991; Balzer, 1992).

Glacial erosional features in the area (striae, rat tails, roches moutonnées, etc.) are indicative of strong regional south to southeast flow directions (Gadd, 1973; Rampton et al., 1984). Multiple striae directions have been reported from several locations (Chalmers, 1902; Seaman, 1991) and attributed to: (1) the interaction of ice masses from different lobes, or (2) different ice caps, or (3) proximity to ice divides (Chalmers, 1902; Gadd, 1973; Rampton et al., 1984; Pronk et al., 1989). However, from examination of cross-cutting relationships in the study area, Balzer (1992) has attributed the southeastward direction to topographic influence on earliest glacier movement. The lack of multiple till units and the gradual change in till composition between sample locations further suggests that this area was covered by a single till sheet deposited from one glacier lobe.

\section{SAMPle COLlection, PREPARATION AND STATISTICS}

Sample collection was accomplished by the senior author, as part of a surficial mapping project for the New Brunswick Department of Natural Resources and Energy (N.B.D.N.R.E.), Fredericton, during the summers of 1990 and 1991. Samples were collected on a $2 \mathrm{~km}^{2}$ grid pattern from natural exposures and excavated sample pits. The material collected was interpreted as unweathered basal till (sensu stricto, Dreimanis, 1976). Sample pits were excavated by hand and sampled at an average depth of $0.75 \mathrm{~m}$ using stainless steel implements. A total of 269 samples were analyzed for grain size and geochemistry. Clast lithologies of 50 to 100 pebbles (clasts $>2 \mathrm{~cm}$ in diameter) were examined in each of 247 samples (Balzer, 1992).

Granulometric analyses were conducted according to ASTM (1964; slightly modified) procedures. The clay-silt fractions (< $0.064 \mu \mathrm{m}$ ) were analyzed geochemically. Atomic Absorption Spectrophotometry (A.A.S.), performed by the N.B.D.N.R.E. Geochemical Lab, was used to determine base metal concentrations. Trace and Rare Earth element abundances were obtained by Activation Labs Limited, using Induced Neutron Activation Analysis (I.N.A.A.). Anomalous geochemical values were determined using the Cumulative Curve Method. Distributions of component abundances were plotted by hand. Sand, silt and clay content were determined according to ASTM (1964) and granulometric statistics were calculated according to Folk (1974). The Statistical Package for Social Sciences produced no significant correlations in the data.

\section{RESULTS AND INTERPRETATIONS}

\section{Matrix}

Analysis of till matrices indicate that the tills are of a relatively homogeneous granulometric content, uniformly poorly sorted (2.0-4.0 $\phi)$ and closely reflect the colour and lithology of the underlying bedrock. Certain elements are elevated in tills overlying specific bedrock units. Chromium and nickel values are highest in till overlying metasedimentary bedrock units in the northwestern part of the study area. Cerium, molybdenum, tantalum, uranium and zinc are highest in till overlying the granites and the tonalite. High silver concentrations ( $>2 \mathrm{ppm}$ ) are also found to be associated with the Hartfield Tonalite (Fig. 2).

For most elements, concentrations rarely exceed background limits. Where anomalous values occur they form dispersal patterns elongated to the southeast, with lengths rarely exceeding $4 \mathrm{~km}$. Some small circular anomalies are associated with bogs. The numerous peat bogs and swamps in the study area are minerotrophic, (Rose et al., 1979) concentrating elements transported to them from surrounding sediments. Small anomalies surrounding bogs possibly originated in this manner.

Geochemical anomalies are observed near known mineral occurrences in the area. The best example of dispersion is related to mineralization at the Lake George Mine site. There, antimony, gold and arsenic form well-defined anomalies elongated southward over $6 \mathrm{~km}$ (e.g., Fig. 3). For the most part, geochemical dispersal patterns are narrow and short in length $(2-5 \mathrm{~km})$ and elongated towards the southeast and south, paralleling local ice-flow directions. These well-defined anomalies occur down-ice of topographic highs suggesting that incorporation of material by grounded ice was better in those areas (cf. Hornibrook et al., 1991). Small anomalies on the flanks of the Pokiok Esker (Figs. 3, 4, 5) may be related to underlying bedrock or be the result of secondary transport during deposition of the esker. 


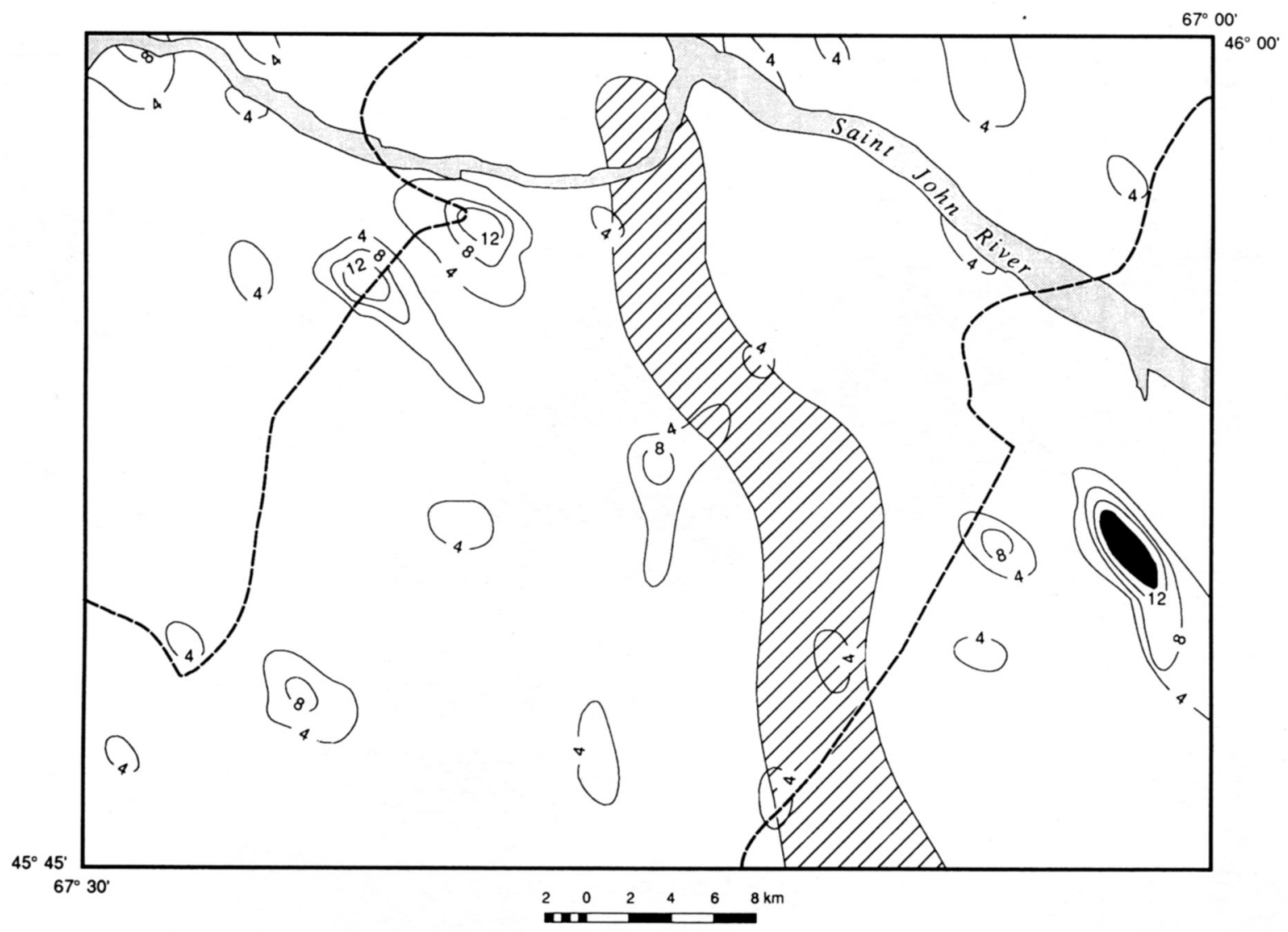

Fig. 3. Dispersal patterns for ppb gold in till. Black area of high concentrations represents the Lake George Mine. The dashed lines represent the northwestern and southeastern contacts of the Pokiok Batholith units with the northern metasedimentary/volcanic rocks and the southern greywacke, slate and conglomerate (see Fig. 2). The hatched area represents the Pokiok Esker and its associated outwash plain.

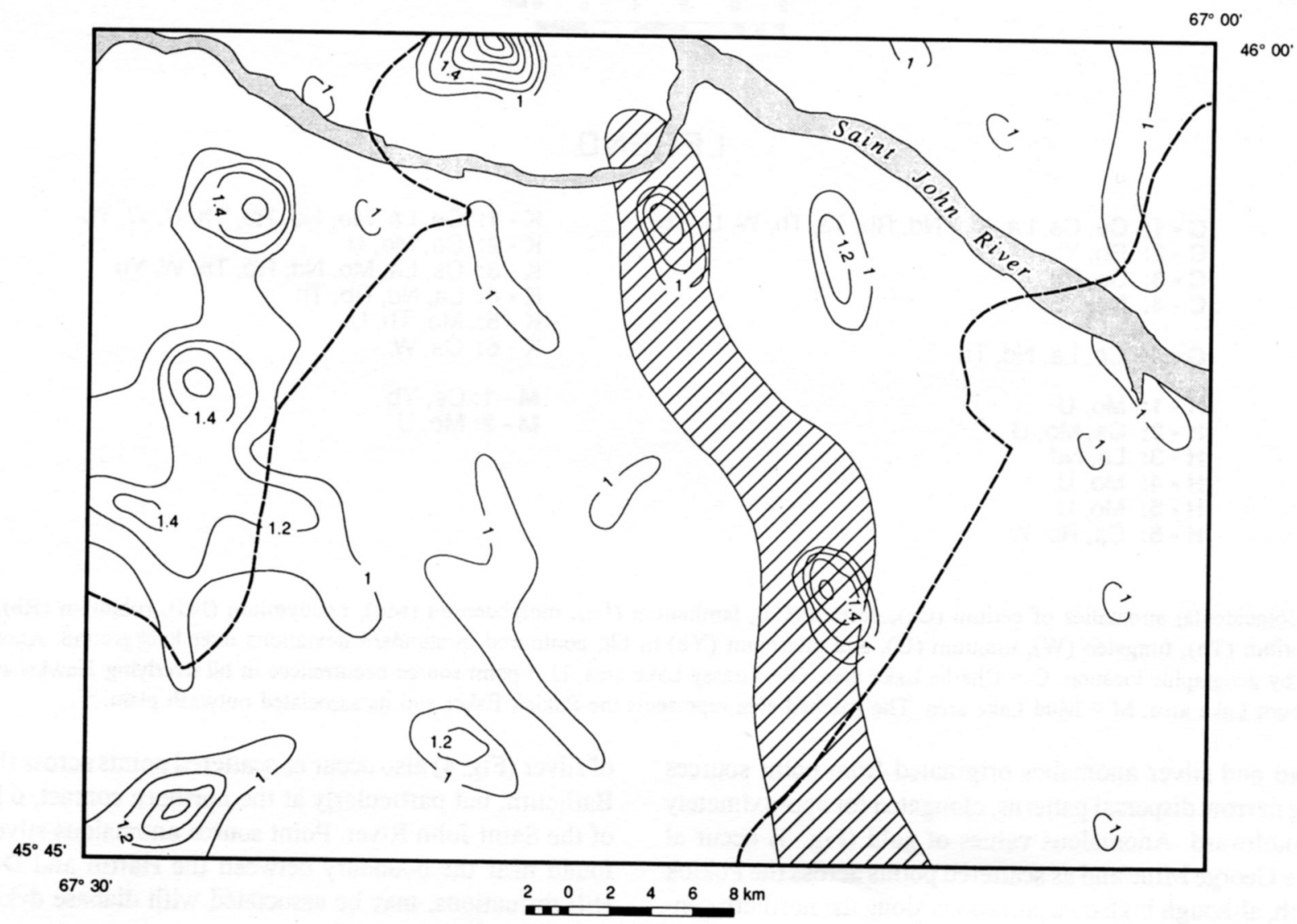

Fig. 4. Dispersal patterns for ppm silver in till. Contacts of Pokiok Batholith (central area) represented by dashed lines (see Fig. 2); the hatched area represents the Pokiok Esker and its associated outwash plain. 


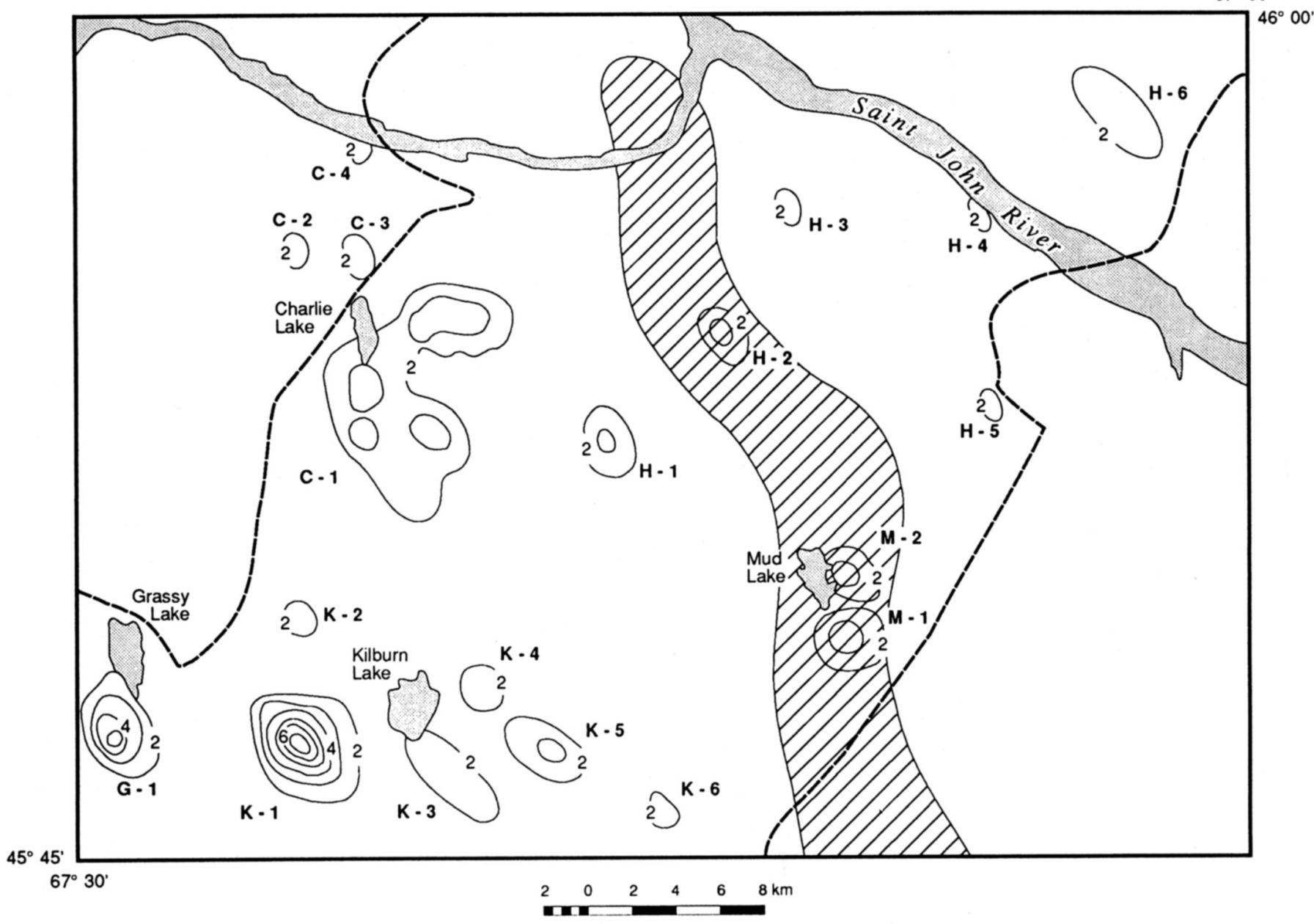

\section{LEGEND}

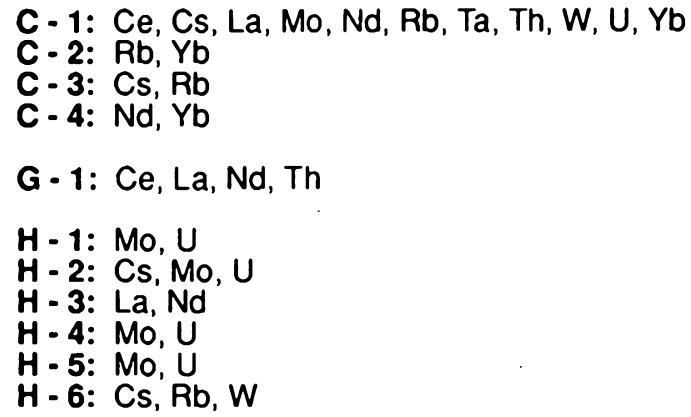

K - 1: Ce, La, Mo, Nd, Rb, Th, U, W, Yb

K- 2: Ce, Mo, U

K - 3: Cs, La, Mo, Nd, Rb, Th, W, Yb

K - 4: La, Nd, Rb, Th

K - 5: Mo, Th, U

$K \cdot 6: C s, W$

$\mathrm{M}-1: \mathrm{Ce}, \mathrm{Yb}$

M- 2: Mo, U

Fig. 5. Coincidental anomalies of cerium (Ce), cesium (Cs), lanthanum (La), molybdenum (Mo), neodymium (Nd), rubidium (Rb), tantalum $(\mathrm{Ta})$, thorium (Th), tungsten (W), uranium (U), and ytterbium ( $\mathrm{Yb}$ ) in till; contoured in standard deviations over background. Anomalies are grouped by geographic location: $C=$ Charlie Lake area, $G=$ Grassy Lake area, $H=$ point source occurrences in till overlying Hawkshaw Granite, $\mathrm{K}=$ Kilburn Lake area, $\mathrm{M}=\mathrm{Mud}$ Lake area. The hatched area represents the Pokiok Esker and its associated outwash plain.

Gold and silver anomalies originated from point sources forming narrow dispersal patterns, elongated for approximately $6 \mathrm{~km}$ southward. Anomalous values of gold (Fig. 3) occur at the Lake George Mine and as scattered points across the Pokiok Batholith, although high concentrations along the northern contact of the unit (within $10 \mathrm{~km}$ south of the Saint John River) indicate a possible stratabound occurrence. Anomalous values of silver (Fig. 4) also occur as scattered points across the Pokiok Batholith, but particularly at the northern contact, $6 \mathrm{~km}$ north of the Saint John River. Point source anomalous silver values, found near the boundary between the Hartin and Dorrington Hill formations, may be associated with diabase dykes in that area (Figs. 2, 4).

Four locations were found to show coincidental elemental 
anomalies: down-ice of pegmatite outcrops near Grassy and Kilburn lakes; south of Charlie Lake; and at Mud Lake along the Pokiok Esker (Fig. 5). The elements include: cesium, molybdenum, cerium, rubidium, tantalum, tungsten, uranium, thorium, lanthanum, ytterbium, and neodymium. The higher values are associated with point sources across the Pokiok Batholith. Further petrologic implications of the element associations remain to be examined.

\section{Pebble Lithologies}

Clast lithologies vary proportionately with movement southward and with change in underlying bedrock lithologies. For example, clasts from the Miramichi Terrane to the northwest occur over most of the area, but decrease in abundance southward, while clasts from units of the Fredericton Cover Sequence in the southeastern part of the area occur only in that portion of the study area. Till overlying the Pokiok Batholith was dominated by granite clasts (Fig. 6). Granite clasts are rare in till overlying the northern portions of the area, although significant granite clast concentrations were traceable over $10 \mathrm{~km}$ southeast of the Pokiok Batholith (Fig. 6).

Aplite, mafic volcanics and granite clasts were found to be particularly useful in distinguishing ice-movement direction. Aplite clasts were found in small amounts $(<10 \%)$, but with distinctive dispersal patterns elongated southeastward. The largest dispersal train (not shown) was found to extend for $20 \mathrm{~km}$ but, because the dispersal pattern contained three areas of high concentration, it was interpreted as a composite pattern from three sources.

Dark green mafic volcanic clasts occur in till overlying metasedimentary units and granites in the western portion of the study area. This lithology decreases gradually, becoming a minor constituent in the till, at about $8 \mathrm{~km}$ southeast of the metasedimentary/granite contact (Fig. 7). Some ribbon-shaped dispersal trains could be traced up-ice for distances over $12 \mathrm{~km}$, to concentrations exceeding $90 \%$ near hills, down-ice of a gabbro dyke (point 11: Fig. 2) and down-ice of the Pocomoonshine Volcanics.

\section{Discussion AND CONCLUSIONS}

During transport, minerals have minimum grain-sizes (terminal grades) to which they can be physically reduced (cf. Dreimanis and Vagners, 1971). Accordingly, clast size is reduced as distance of transport increases, but mineral size is not reduced indefinitely. Nonetheless, the mineralogy of local bedrock should be reflected in coarser grain sizes because of terminal grade. While finer-grained clay and silt may be more representative of material derived from great distances, it can also be

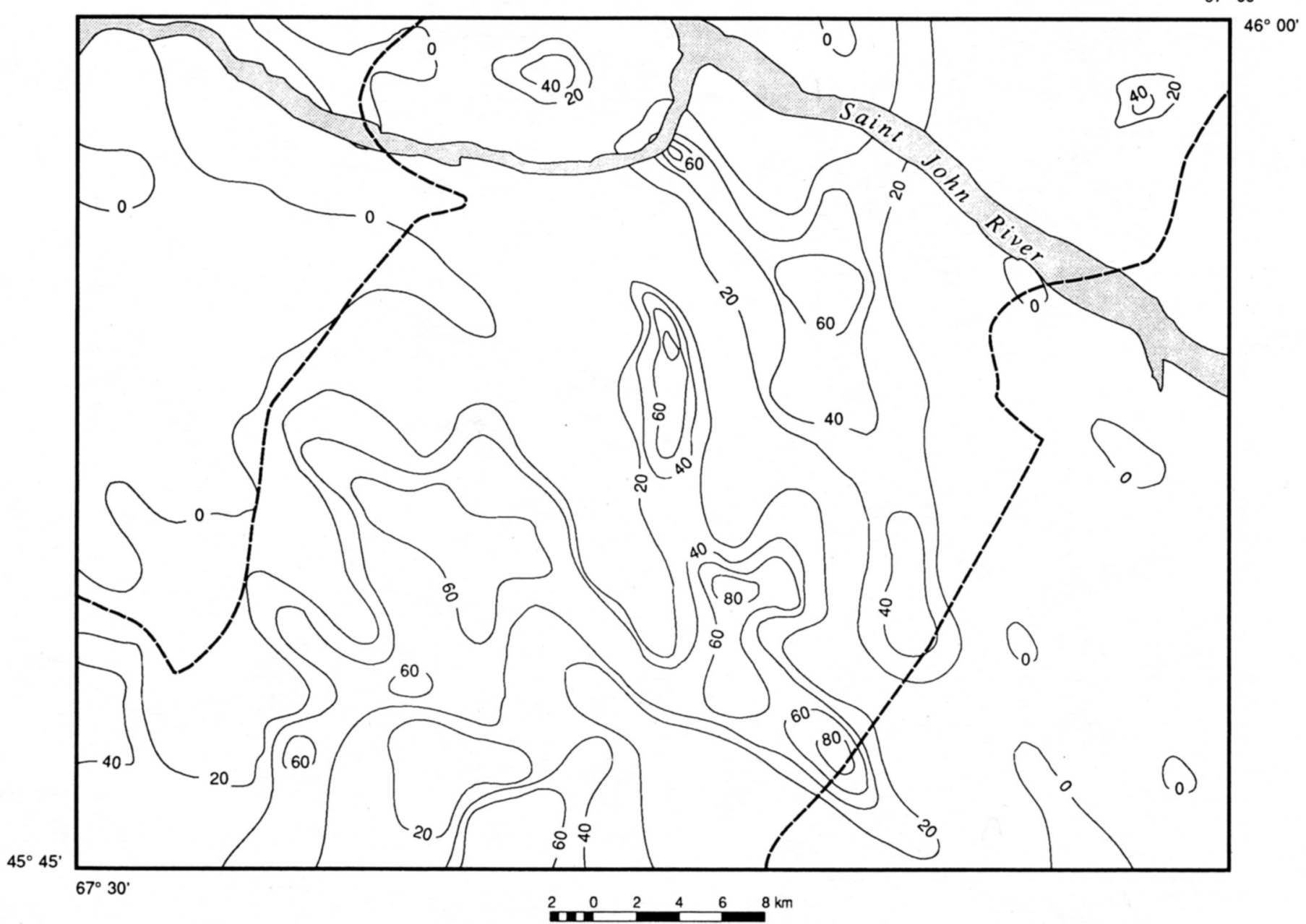

Fig. 6. Dispersal pattern for percent granite clasts in till. Note the increase in granite content and south-southeastward dispersal trains across the Pokiok Batholith (central area between dashed lines). 
incorporated as pre-glacial unconsolidated silt or clay (Broster, 1986). This, or the incorporation of mixed lithologies (Broster, 1986), could account for the poor correlations between geochemical and clast data reported in local studies (Hornibrook et al., 1991, 1993; Balzer, 1992).

May and Dreimanis (1976) suggested that pebble lithologies are more variable than granulometric parameters and thus matrices are inherently more homogeneous as a whole. Our examination of clast and matrix components support this conclusion. Locally, dispersion patterns of geochemical anomalies are small and indistinct. The tills are relatively homogeneous in granulometric content, uniformly poorly sorted and closely reflect the colour and lithology of the underlying bedrock. The abundance of local material in matrix and clast fractions of the sediments, and the rapid change of lithology near contacts, are interpreted to be indicative of short transportation distances.

Some clasts have been transported over $12 \mathrm{~km}$ down-ice from their bedrock source, but dispersal patterns are particularly well-defined at hills. This has previously been reported for Ncw Brunswick tills by Hornibrook et al. (1991), who suggested that it was a function of preferential glacial erosion and incorporation of local bedrock material at topographic highs.

From the dispersal patterns it is inferred that complete mixing of the glacier load was likely achieved within $6 \mathrm{~km}$ of the source for matrix components and $12 \mathrm{~km}$ for clasts. The rapid variation in lithology and texture of the underlying bedrock may have induced changes in the basal thermal regime of the ice during glacial advance that facilitated compositional homogenization (cf. Broster, 1986).

In New Brunswick, the size of the initial sampling grid influences the morphology of dispersal anomalies. A $2 \mathrm{~km}^{2}$ sampling grid suffices for clast analyses because their dispersal patterns are typically large and thus easily identifiable. Conversely, most geochemical dispersion anomalies in the study area were less than $3 \mathrm{~km}$ long and defined by one to three sample sites. Shilts (1976) suggested that geochemical analyses using large sampling grids rarely give accurate dispersal patterns. This is further supported by the observations herein, as well as other studies (e.g., Hornibrook et al., 1991, 1993), indicating that sampling at closer intervals is needed to properly define local geochemical anomalies.

\section{ACKNOWLEDGEMENTS}

The authors wish to thank M. Parkhill and A.G. Pronk for their reviews and improvements of an earlier draft. We are particularly grateful to A.A. Seaman for logistical support and enlightening discussions. Field support and geochemical analyses were provided to S.A. Balzer by the New Brunswick Department of Natural Resources and Energy. Support for publication was received from an NSERC Operating Grant to B.E. Broster.

$67^{\circ} 00^{\circ}$

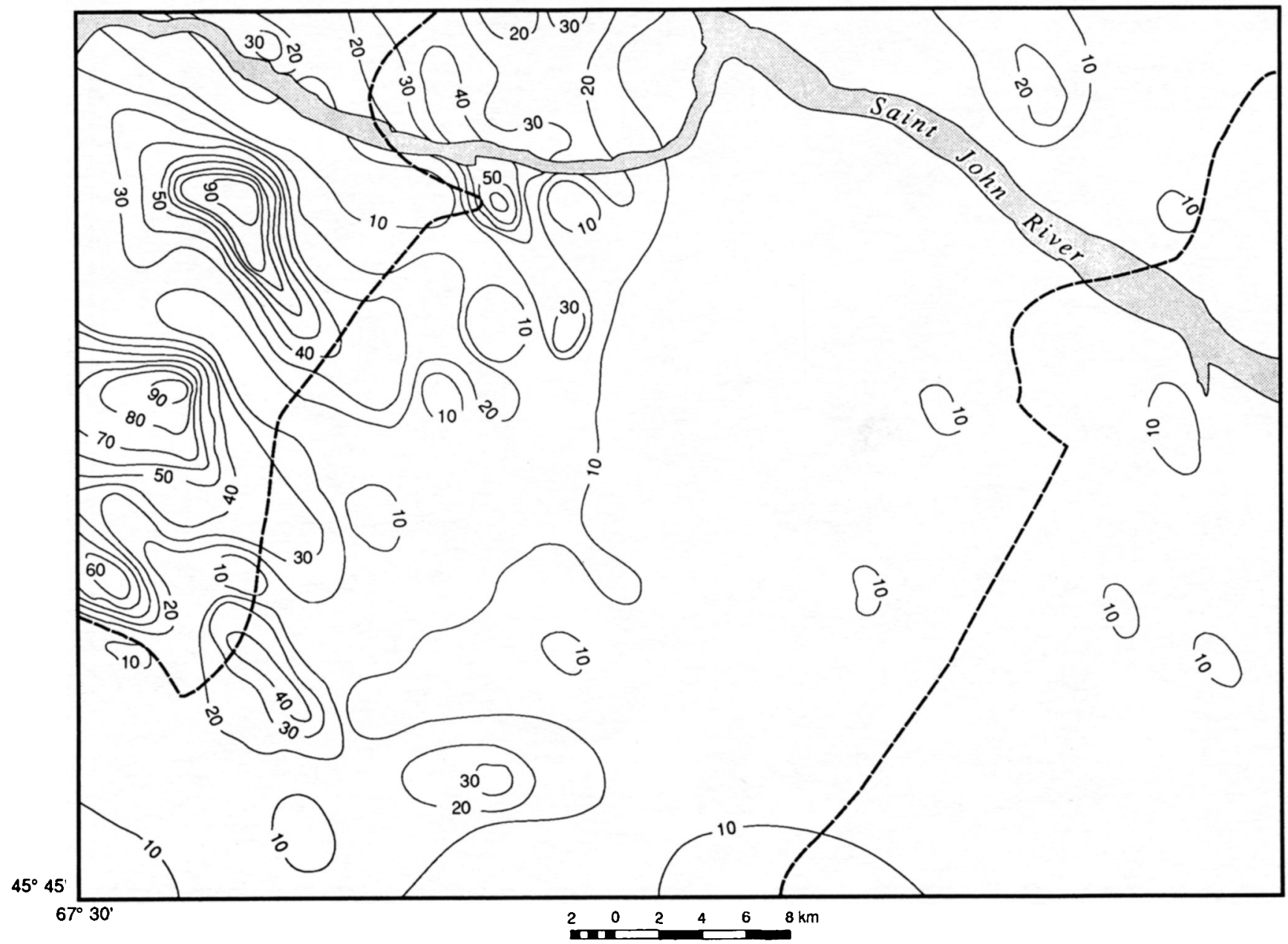

Fig. 7. Dispersal pattern for percent volcanic clasts showing their rapid decrease and paucity in till after $10 \mathrm{~km}$ transport southeast of the contact of the metasedimentary/volcanics (northwestward of the western dashed line) with the Pokiok granite units (central area between dashed lines). 
American Society for Testing and materials 1964. Procedures for testing soils. Fourth edition. Philadelphia, Pennsylvania, 539 p.

Anderson, F.D. and Poole, W.H. 1959. Geology of Woodstock Fredericton, York, Carleton, Sunbury and Northumberland Counties, New Brunswick. Map 37-1959, scale 1:126,720.

BALzer, S.A. 1992. Quaternary geology and dispersal patterns of the Canterbury area, New Brunswick. M.Sc. thesis, University of New Brunswick, 192 p.

BeVIER, M.L. 1988. U-Pb geochronologic studies of igneous rocks in N.B. In Thirteenth Annual Review of Activities, Project Résumés. Edited by S.A. Abbott. New Brunswick Department of Natural Resources and Energy, Minerals and Energy Division, Information Circular 88-2, pp. 134-140.

Bostock, H.S. 1970. Physiographic regions of Canada. Geological Survey of Canada, Map 1254A.

BROSTER, B.E. 1986. Till variability and compositional stratification: examples from the Port Huron lobe. Canadian Journal of Earth Sciences, 23, pp. 1823-1841.

Broster, B.E. and Seaman, A.A. 1991. Glacigenic rafting of weathered granite: Charlie Lake, New Brunswick. Canadian Journal of Earth Sciences, 28, pp. 649-654.

Chalmers, R. 1902. Report on the Surface Geology shown on the Fredericton and Andover Quarter-Sheet Maps, New Brunswick. Geological Survey of Canada, Annual Report 1899, Vol. XII, Part M.

CokeR, W.B. and Dilabio, R.N.W. 1989. Geochemical exploration in glaciated terrain: geochemical responses. Exploration '87, Ontario Geological Survey, Special Volume 3, pp. 336-383.

Dilabio, R.N.W. 1990. Chapter 7: Glacial dispersal trains. In Glacial Indicator Tracing. Edited by R. Kujansuu and M. Saarnisto. A.A. Balkema, Rotterdam, pp. 109-122.

Dreimanis, A. 1958. Tracing ore boulders as a prospecting method in Canada. Canadian Mining and Metallurgical Transactions, 61, pp. 49-56.

1976. Tills: their origin and properties: In Glacial Till: An Inter-Disciplinary Study. Edired by R.F. Legget. Royal Society of Canada, Special Publication, 12, pp. 11-49.

Dreimanis, A. and Vagners, U.J. 1971. Bimodal distribution of rock and mineral fragments in basal tills. In Till: A Symposium. Edited by R.P. Goldthwait. Ohio State University Press, pp. 237. 250.

Folk, R.L. 1974. Petrology of Sedimentary Rocks. Hemphill Publishing Company, Austin, Texas, $170 \mathrm{p}$.

FYFFE, L.R. and FRICKER, A. 1987. Tectonostratigraphic terrane analysis of New Brunswick. Maritime Sediments and Atlantic Geology, 23, pp. 113-223.

Fyffe, L.R., PajarI, G.E., and Cherry, M.E. 1981. The Acadian Plutonic rocks of New Brunswick. Maritime Sediments and Atlantic Geology, 17, pp. 23-36.

GADD, N.R. 1973. Quaternary Geology of southwest New Brunswick, with particular reference to Fredericton area. Geological Survey of Canada, Paper 71-34, $31 \mathrm{p}$.

Hicock, S.R. 1986. Pleistocene glacial dispersal and history in Buttle valley, Vancouver Island, British Columbia: a feasibility study for alpine drift prospecting. Canadian Journal of Earth Sciences, 23, pp. 1867-1879.

Hornibrook, E.R.C., Broster, B.E., Gardiner, W.W., and Pronk, A.G. 1991. Glacial dispersal of heavy minerals in Late Wisconsinan
Till, central New Brunswick. Atlantic Geology, 27, pp. 199-208.

1993. Glacial dispersal of garnets and other heavy minerals in till: Miramichi area, New Brunswick. Journal of Exploration and Mining Geology, 2, pp. 345-353.

Lutes, G. 1979. Geology of Fosterville - North and Eel Lakes Map Area G-23 and Canterbury - Skiff Lake Map Area H-23 (Parts of $21 \mathrm{G} / 13$ and $21 \mathrm{G} / 14$ ). New Brunswick Department of Natural Resources, Mineral Resources Branch, Map Report 79-3 and Plates 79-25A and 79-26A.

1987. Geology and Geochemistry of the Pokiok Batholith, New Brunswick. New Brunswick Department of Natural Resources, Minerals and Energy Division, Report of Investigation 22 and Plates 80-101(R) and 80-102(R).

MaY, R.W. and Dreimanis, A. 1976. Compositional variability in tills. In Glacial Till: An Inter-Disciplinary Study. Edited by R.F. Legget. Royal Society of Canada, Special Publication 12, pp. 99-119.

McConnell, J.W. and BatTerson, M.J. 1987. The Strange Lake Zr-Y$\mathrm{Nb}-\mathrm{Be}$-REE deposit, Labrador: a geochemical profile in till, lake and stream sediment, and water. In Geochemical Exploration 1985. Edited by R.G. Garrett. Journal of Geochemical Exploration, 29, pp. 105-127.

Pronk, A.G., Bobrowsky, P.T., and Parkhill, M.A. 1989. An interpretation of Late Quaternary glacial flow indicators in the Baie des Chaleurs region, northern New Brunswick. Géographie physique et Quaternaire, 43, pp. 179-190.

Rampton, V.N., Gauthier, R.C., Thibault, J., and Seaman, A.A. 1984. Quaternary Geology of New Brunswick. Geological Survey of Canada, Memoir 416 and Map 1594A, scale 1:500,000.

Rose, A.W., Hawkes, H.E., and WebB, J.S. 1979. Geochemistry in Mineral Exploration. Second edition. Academic Press, London, United Kingdom, $657 \mathrm{p}$.

RuitenberG, A.A., Johnson, S.C., and FyfFe, L.R. 1990. Epigenetic gold deposits and their tectonic setting in the New Brunswick Appalachians. Canadian Institute of Mining and Metallurgy, Bulletin 83, No. 934, pp. 43-55.

Seaman, A.A. 1991. Complex glacial ice-flow events in New Brunswick with particular reference to the Oromocto Lake area, and implications for drift prospecting. New Brunswick Department of Natural Resources and Energy, Mineral Resources, Geoscience Report 89-2 and Plate 89-11.

SHILTS, W.W. 1976. Glacial till and mineral exploration. In Glacial Till: An Inter-Disciplinary Study. Edited by R.F. Legget. Royal Society of Canada, Special Publication 12, pp. 205-224.

1984. Till geochemistry in Finland and Canada. Journal of Geochemical Exploration, 21, pp. 95-117.

VAN StAAL, C.R. and FyfFe, L.R. 1991. Dunnage and Gander Zones, New Brunswick: Canadian Appalachian Region. New Brunswick Department of Natural Resources and Energy, Mineral Resources, Geoscience Report 91-2, 39 p.

Venugopal, D.V. 1979. Geology of Debec Junction - Gibson Millstream - Temperance Vale - Meductic Region Map Areas G-21, H-21, I21 , and $\mathrm{H}-22$ (Parts of $21 \mathrm{~J} / 3,21 \mathrm{~J} / 4,21 \mathrm{G} / 13$, and 21G/14). New Brunswick Department of Natural Resources, Mineral Resources Branch, Map Report 79-5 and Plates 78-27A, 78-30A, 78-31A, and 78-32A.

WhALEN, J.B. 1993. Geology, petrography, and geochemistry of Appalachian granites in New Brunswick and Gaspésie, Quebec. Geological Survey of Canada, Bulletin 436, 124 p. 